Case reports

\title{
Occurrence of the $\alpha$ thalassaemia-mental retardation syndrome (non-deletional type) in an Australian male
}

\author{
M P Harvey, A Kearney, A Smith, R J Trent
}

\begin{abstract}
The rare association of $\alpha$ thalassaemia and mental retardation has been described previously. Molecular studies of the $\alpha$ globin cluster in these cases have been heterogeneous, with some patients having large deletions while in others the $\alpha$ globin complex appears to be intact (non-deletional). The non-deletional cases form a distinct group whose features include severe mental retardation, haematological changes of haemoglobin $\mathrm{H}$ (Hb H) disease, developmental defects, and unusual patterns of inheritance. To date, five cases have been described with non-deletional $\alpha$ thalassaemia-mental retardation. We present here a further example of a young male of Northern European origin who appears to have the non-deletional form of the disease. Clinical features included severe mental retardation, $\mathrm{Hb} \mathbf{H}$ disease, and developmental defects similar to those reported previously. DNA mapping, including pulsed field electrophoresis, showed no evidence of deletions within the $\alpha$ globin cluster. Karyotypic analysis indicated an increase in random breakage, which has been observed previously in one case of deletional $\alpha$ thalassaemia-mental retardation. Profuse $\mathrm{Hb} \mathrm{H}$ bodies and $\mathrm{Hb} \mathrm{H}$ on electrophoresis were consistent with $\mathrm{Hb} \mathrm{H}$ disease. However, the latter was present at a relatively low level (1.6\%) and, as well, the mean corpuscular volume $(82.8 \mathrm{fl})$
\end{abstract}

\footnotetext{
Molecular Biology Laboratory, Clinical Immunology Research Centre, University of Sydney, NSW 2006, Australia.

M P Harvey, A Kearney, R J Trent

Oliver Latham Laboratories, PO Box 53, North Ryde 2113, Australia.

A Smith

Correspondence to Dr Harvey.
}

Received for publication 1 March 1990.

Accepted for publication 21 March 1990. and mean corpuscular haemoglobin $(26.4 \mathrm{pg})$ were surprisingly high. Our findings are compared to other cases described with the non-deletional $\mathbf{H b}$ H-mental retardation syndrome.

The human $\alpha$ globin cluster is located on the terminal band of the short arm of chromosome 16, 16p13.3. ${ }^{12}$ The genes are arranged in order of developmental expression, with embryonic zeta $(\xi)$ at the $5^{\prime}$ end, followed by the three pseudogenes $\psi \xi \xi, \psi \alpha_{2}$, and $\psi \alpha_{1}$, the duplicated adult genes $\alpha_{2}$ and $\alpha_{1}$, and the incompletely characterised $\theta$ at the $3^{\prime}$ end. The $\alpha$ thalassaemia syndromes result from reduced expression of one to four of the normal diploid complement of $\alpha$ globin genes. In contrast to the $\beta$ thalassaemias, most of the $\alpha$ thalassaemias result from deletions, with point mutations occurring much less commonly. Persons with one gene deletion $(-\alpha / \alpha \alpha)$ may have normal haematological parameters. Deletions of two $\alpha$ globin genes (either $--/ \alpha \alpha$ or $-\alpha /-\alpha$ ) produce a mild, asymptomatic, hypochromic, microcytic anaemia. Three gene deletions $(--/-\alpha)$ give the phenotype of $\mathrm{Hb} \mathrm{H}$ disease. Clinically, $\mathrm{Hb} \mathrm{H}$ disease may vary from asymptomatic to a severe, blood transfusion dependent anaemia. Typically, prominent hypochromic microcytic changes of the red cells are found. On incubation of the blood with supravital dyes, such as methylene blue, profuse $\mathrm{Hb} \mathrm{H}$ bodies are seen. These are the result of precipitation of $\beta$ chain tetramers secondary to unbalanced globin chain synthesis. The association of $\alpha$ thalassaemia and mental retardation has been reported previously, often with the accompanying features of facial abnormalities, hypogonadism, and other developmental defects. ${ }^{2-9}$ Recently, Wilkie $e t$ $a l^{10} " 1$ have shown that two distinct subgroups can be identified within the $\alpha$ thalassaemia-mental retardation syndrome. One group (eight cases) have extensive deletions within $16 \mathrm{pl} 3.3$, with variable somatic defects. A second group of five karyotypic males have 
no demonstrable deletions, severe mental impairment, and a more homogeneous pattern of associated abnormalities. This report describes the clinical, cytogenetic, and molecular features found in an additional male patient with the non-deletional $\alpha$ thalassaemia-mental retardation syndrome, and compares the findings with the previously described cases.

\section{Case report}

The proband was born in 1968 to parents who were said to be of normal intelligence and unrelated. Pregnancy was complicated by severe pre-eclampsia, requiring induction at 35 weeks and instrumental delivery. His birth weight was $2272 \mathrm{~g}$ (50th centile for 35 weeks' gestation). At the time of delivery, his mother was aged 18 and his father 19. Shortly after delivery, the mother's urine was found to be positive for tuberculosis. There was no evidence of infection in the proband. At 9 months, he was investigated because of poor milestones. He was found to have a flat nasal bridge, epicanthic folds, hypertelorism, and bilateral undescended testes. His head circumference was $44.5 \mathrm{~cm}$ (3rd to 10th centile) and inner canthal distance was $3.2 \mathrm{~cm}$ ( $>97$ th centile). Subsequently, the proband has remained profoundly mentally retarded, with failure of development of speech and inability to walk unsupported.

There was one other sib, a male, born in 1971, who died in childhood. The latter was also profoundly mentally retarded and said to have a similar physical appearance, but no other details are available. From the age of 10 , the proband was institutionalised. His parents separated and were then lost to further contact. There is no record of any normal children. Extensive metabolic and cytogenetic testing failed to show a cause for his mental retardation. Recurrent urinary tract infections and grand mal seizures have been a feature over the years. In 1986, at the age of 18 , swelling of the small joints of both hands and deterioration in hand grip were noted. Antinuclear antibodies, rheumatoid factor, serum hepatitis B surface antigen ( $\mathrm{HBsAg}$ ), and biochemical analysis were normal and a hypochromic microcytic anaemia was found. At present, at the age of 21 , his height is $150 \mathrm{~cm}$ ( $<3$ rd centile), weight $44.5 \mathrm{~kg}$ ( $<3 \mathrm{rd}$ centile), and head circumference $51 \mathrm{~cm}(<2$ nd centile), with an inner canthal distance of $3.5 \mathrm{~cm}$ (75th to 97 th centile) (figure). He has a mild thoracic scoliosis, uncorrected left sided talipes equinovarus, and small, soft descended testes, high in the scrotum.

\section{HAEMATOLOGICAL FINDINGS}

Peripheral blood was obtained for haematological study, cytogenetic analysis, and the establishment of EBV transformed lymphoblastoid lines. Blood count

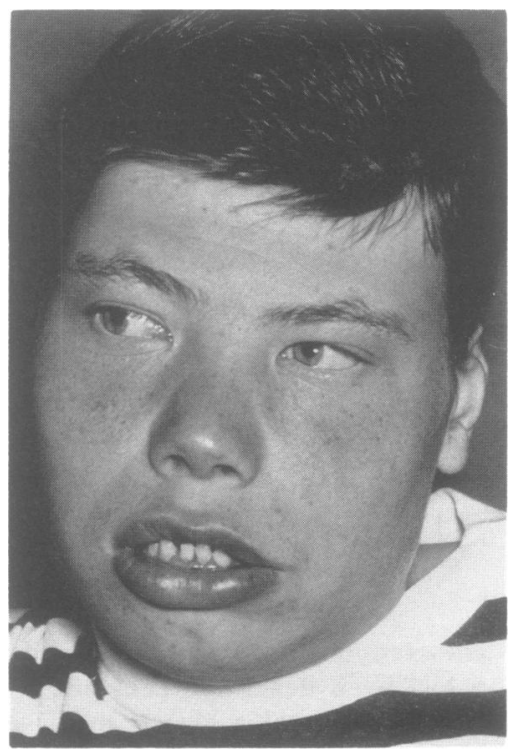

The proband aged 21 years.

and haematological indices were measured on a Coulter model S Plus cell counter. The haematological findings are summarised in table 1 . There was evidence of a hypochromic microcytic anaemia, as well as iron deficiency. Results, after successful therapy with oral iron supplements, are also listed in table 1 . Profuse $\mathrm{Hb} \mathrm{H}$ bodies ( 5 to $7 \%$ ) were present after two hours' incubation with new methylene blue. There was no increase in the number of $\mathrm{Hb} \mathrm{H}$ bodies after overnight incubation, and there was no evidence of an unstable haemoglobin on either isopropanol or heat instability testing. On cellulose acetate $\mathrm{Hb}$ electrophoresis (Hb EPG), $\mathrm{Hb} \mathrm{H}$ was estimated to be

Table 1 Haematological data on index case before and after iron therapy.

\begin{tabular}{|c|c|c|c|}
\hline & $\begin{array}{l}\text { Before } \\
\text { iron }\end{array}$ & $\begin{array}{c}\text { After } \\
\text { iron }\end{array}$ & $\begin{array}{l}\text { Normal } \\
\text { range }\end{array}$ \\
\hline Haemoglobin (g/dl) & $11 \cdot 3$ & $12 \cdot 1$ & $13 \cdot 0-18 \cdot 0$ \\
\hline $\begin{array}{l}\left(\times 10^{9} / 1\right) \\
\text { Platelet count }\left(\times 10^{9} / 1\right)\end{array}$ & & $\begin{array}{l}8 \cdot 1 \\
293\end{array}$ & $\begin{array}{l}4 \cdot 0-11 \cdot 0 \\
150-500\end{array}$ \\
\hline $\begin{array}{l}\text { Reticulocyte } \\
\text { count }(\%)\end{array}$ & & 1.8 & $0 \cdot 2-2 \cdot 0$ \\
\hline $\begin{array}{l}\operatorname{MCV}(\mathbf{f l}) \\
\mathrm{MCH}(\mathrm{pg}) \\
\mathrm{Hb} \mathrm{A}_{2}(\%)\end{array}$ & $\begin{array}{l}77 \cdot 6 \\
24 \cdot 8 \\
2 \cdot 1\end{array}$ & $\begin{array}{l}82 \cdot 8 \\
26 \cdot 4 \\
1 \cdot 5\end{array}$ & $\begin{array}{l}76-96 \\
27-31 \\
1 \cdot 5-3 \cdot 7\end{array}$ \\
\hline $\begin{array}{l}\text { Kleihauer test } \\
\mathrm{Hb} \mathbf{H} \text { bodies (\%) }\end{array}$ & $\begin{array}{l}\text { Normal } \\
5-7\end{array}$ & $\begin{array}{l}\text { Normal } \\
5-7\end{array}$ & $20-2$ \\
\hline Hb EPG & $\begin{array}{l}\text { Faint } \mathrm{Hb} \\
\mathrm{H} \text { band }\end{array}$ & $1.6 \% \mathrm{Hb} \mathrm{H}$ & 0 \\
\hline $\begin{array}{l}\text { Serum ferritin } \\
(\mu \mathrm{g} / \mathrm{l}) \\
\text { Serum B12 (ng/l) } \\
\text { Serum folate }(\mu \mathrm{g} / \mathrm{l})\end{array}$ & 10 & $\begin{array}{l}70 \\
483 \\
>20\end{array}$ & $\begin{array}{l}20-300 \\
200-800 \\
3 \cdot 2-24\end{array}$ \\
\hline
\end{tabular}

$\mathrm{MCH}=$ mean corpuscular haemoglobin; $\mathrm{MCV}=$ mean corpuscular volume; $\mathrm{EPG}=$ electrophoretogram. 
Table 2 A summary of the clinical and haematological findings in the reported cases of $\alpha$ thalassaemia-mental retardation (non-deletional type).

\begin{tabular}{|c|c|c|c|c|}
\hline Reference & Case & $\begin{array}{l}\text { Haematological } \\
\text { findings }\end{array}$ & Phenotype & Family \\
\hline $3,8,11$ & $\begin{array}{l}\text { 'PT' in } 11, \\
\text { Male age } 17 \mathrm{y}\end{array}$ & $\begin{array}{l}\text { Hb H } 6 \cdot 7 \% \\
\text { MCV } 90 \mathrm{fl} \\
\text { MCH } 25 \mathrm{pg}\end{array}$ & $\begin{array}{l}\text { Microcephaly, hypertelorism, seizures, } \\
\text { cryptorchidism, flat face } \\
\text { and nasal bridge }\end{array}$ & $\begin{array}{l}\text { Mother had phenotypic } \\
\text { evidence of }-\alpha / \alpha \alpha \text {. father normal }\end{array}$ \\
\hline 3,11 & $\begin{array}{l}\text { 'SW' in } 11, \\
\text { Male age } 8 \text { y }\end{array}$ & $\begin{array}{l}\text { Hb H } 2 \cdot 5 \% \\
\text { MCV } 70 \text { fl } \\
\text { MCH } 22 \mathrm{pg}\end{array}$ & $\begin{array}{l}\text { Microcephaly, hypertelorism, seizures, } \\
\text { cryptorchidism, flat face } \\
\text { and nasal bridge, } \\
\text { epicanthic folds }\end{array}$ & As for previous patient \\
\hline 11 & $\begin{array}{l}\text { 'TH' in } 11, \\
\text { Male age } 2 \mathrm{y}\end{array}$ & $\begin{array}{l}\text { Hb H } 1 \% \\
\text { MCV } 74 \cdot 3 \mathrm{fl} \\
\text { MCH } 23.8 \mathrm{pg}\end{array}$ & $\begin{array}{l}\text { Microcephaly, hypertelorism, seizures, } \\
\text { cryptorchidism, flat face } \\
\text { and nasal bridge, } \\
\text { epicanthic folds, } \\
\text { unilateral talipes }\end{array}$ & $\begin{array}{l}\text { Normal } \alpha / \beta \text { globin chain } \\
\text { synthesis ratios in } \\
\text { parents }\end{array}$ \\
\hline 11 & $\begin{array}{l}\text { 'NE' in } 11 \text {, } \\
\text { phenotypic female } \\
\text { age } 4 \mathrm{y}\end{array}$ & $\begin{array}{l}\text { Hb H } 0.7 \% \\
\text { Male karyotype } \\
(46, X Y) \\
\text { MCV } 69 \cdot 7 \text { fl } \\
\text { MCH } 21 \cdot 7 \mathrm{pg}\end{array}$ & $\begin{array}{l}\text { Female external genitalia, } \\
\text { abdominal testes, microcephaly, } \\
\text { hypertelorism, epicanthic folds, } \\
\text { flat nasal bridge }\end{array}$ & $\begin{array}{l}\text { Haematology normal in } \\
\text { parents. } \\
\alpha / \beta \text { globin chain } \\
\text { synthesis ratios not done }\end{array}$ \\
\hline 11 & $\begin{array}{l}\text { 'PE' in } 11, \\
\text { male age } 2 \mathrm{y}\end{array}$ & $\begin{array}{l}\text { Hb H } 3 \cdot 5 \% \\
\text { MCV } 74 \mathrm{fl} \\
\text { MCH } 22.9 \mathrm{pg}\end{array}$ & $\begin{array}{l}\text { Hemivertebra, small ears, } \\
\text { cryptorchidism, convergent } \\
\text { squint, hypoplastic } \\
\text { teeth }\end{array}$ & $\begin{array}{l}\text { Parents had normal } \\
\text { haematology and } \alpha / \beta \\
\text { globin chain synthesis } \\
\text { ratios }\end{array}$ \\
\hline Present report & Male age $21 \mathrm{y}$ & $\begin{array}{l}\text { Hb H } 1 \cdot 6 \% \\
\text { MCV } 82 \cdot 8 \mathrm{fl} \\
\text { MCH } 26 \cdot 4 \mathrm{pg}\end{array}$ & $\begin{array}{l}\text { Microcephaly, unilateral } \\
\text { talipes, hypertelorism, } \\
\text { late descent of testes, } \\
\text { flat nasal bridge, } \\
\text { epicanthic folds }\end{array}$ & Parents not available \\
\hline
\end{tabular}

$1 \cdot 6 \%$. An $\alpha / \beta$ ratio of 0.54 was consistent with either a two gene deletion $(-\alpha /-\alpha$ or $--/ \alpha \alpha)$ or $\mathrm{Hb} \mathrm{H}$ disease $(--l-\alpha) .^{12}$ Red cell glutathione peroxidase, glucose 6 phosphate dehydrogenase, triose phosphate isomerase, phosphoglycerokinase, and glutathione reductase levels were normal.

\section{GENE MAPPING}

DNA was prepared from $10^{8}$ EBV transformed lymphoid cells, ${ }^{13}$ digested with restriction endonuclease enzymes (Boehringer Mannheim) according to the manufacturer's instructions, electrophoresed on $0.8 \%$ agarose gels, and transferred by Southern blotting to nylon (Hybond, Amersham) using established techniques. ${ }^{14} \alpha$ and $\xi$ probes were gifts of $\mathrm{Dr}$ D R Higgs, MRC Molecular Haematology Unit, Institute of Molecular Medicine, John Radcliffe Hospital, Oxford. DNA was digested with the enzymes BamHI, BglII, EcoRI, SacI, and HindIII and probed with $\alpha$ and $\xi$ probes. There was no evidence of deletions or rearrangements within the $\alpha$ globin cluster. The finding of two polymorphic bands with the SacI digest, hybridised with the $\xi$ probe, showed that both $\alpha$ globin loci were present.

DNA for pulsed field electrophoresis was prepared from fresh lymphoblastoid cells, and the restriction endonuclease digestions were performed according to the method of Smith et al. ${ }^{16}$ Specimens were then run by transverse alternating field electrophoresis (Geneline $^{\mathrm{TM}}$, Beckman) according to the manufacturer's instructions. Conditions were chosen to give maximum resolutions in the 200 to $800 \mathrm{~kb}$ range. Digests with NotI, PvuI, XhoI, SacII, BglI, MluI, $S a l$, ClaI, and $S f i \mathrm{I}$ were probed with the $\alpha$ and $\xi$ probes. No deletions were detected when DNA from the proband was electrophoresed in parallel with normal controls.

\section{CYTOGENETIC ANALYSIS}

Cytogenetic analysis was performed on 92 hour peripheral blood cultures set up in deprived medium (Iscoves's low folate and FdU), looking for the folate sensitive fragile site on $16 \mathrm{pl}$, and analysed with high resolution techniques. ${ }^{17}$ High resolution analysis to the 700 band stage failed to show an obvious deletion or translocation. Fragile site analysis showed nine random breaks in seven out of 55 cells on one occasion, and 22 breaks in 13 of 50 cells on a second occasion. This is higher than the normal ( 2 to $5 \%$ ) for the laboratory. There was no pattern to the breaks, with some constituting common fragile sites. In particular, no fragile $\mathrm{X}$ chromosome was seen.

\section{Discussion}

The syndrome of $\mathrm{Hb} \mathrm{H}$-mental retardation was first 
well defined by Weatherall et al. ${ }^{3}$ Recently, Wilkie $e t$ $a l^{10} 11$ have extensively investigated these original three cases, four other cases described elsewhere, ${ }^{2-9}$ as well as six unreported cases. Of this total of 13 cases, eight had extensive DNA deletions involving 16p13.3 (five had cytogenetic abnormalities), whereas five had no demonstrable deletions. Clinically, the five non-deletional cases of $\alpha$ thalassaemia-mental retardation were a much more homogeneous group. The significant findings in these five cases of nondeletional $\alpha$ thalassaemia-mental retardation plus the present case are summarised in table 2 .

The cases described in table 2 have several features in common, which include facial, genital, and forefoot abnormalities, hypertelorism, seizures, and mild $\mathrm{Hb}$ $\mathrm{H}$ disease, all of which were present in our patient. In cases 'PT' and 'SW', the family studies are noteworthy, since the father was haematologically normal and the mother had evidence of heterozygous nondeletional $\alpha+$ thalassaemia $(-\alpha / \alpha \alpha)$. Hence the suggestion was made ${ }^{3}$ that the $\alpha^{0}$ thalassaemic haplotype inherited from the father may represent a paternal germline mutation. As previously commented, "all the cases described so far have occurred in chromosomal males, including the present example. The inability to perform family studies in the case of our proband was unfortunate, particularly given the history of a male sib with mental retardation and similar physical features.

Some of the haematological findings in the proband are intriguing. The profuse $\mathrm{Hb} \mathrm{H}$ bodies and detectable $\mathrm{Hb} \mathrm{H}$ on EPG are diagnostic of $\mathrm{Hb} \mathrm{H}$ disease. Although the $\alpha / \beta$ globin chain ratio of 0.54 is consistent, the $\mathrm{MCV}$ and $\mathrm{MCH}$ are surprisingly high. ${ }^{12}$ This has been a conspicuous feature of the previously described cases of non-deletional $\alpha$ thalassaemia-mental retardation, suggesting a different mechanism from the commonly encountered cases of $\mathrm{Hb} \mathrm{H}$ disease. ${ }^{11}$ The increase in random chromosomal breaks in the proband is an interesting observation, and was described in a patient with deletional $\alpha$ thalassaemia-mental retardation. ${ }^{45}$ Here, evidence of increased chromosomal breakage was found in the father as well. In both this case and our case, the breaks detected were randomly distributed. In the present case, despite an increased level of breakage, none was seen in $16 \mathrm{pl} 2$ which is the rare fragile site adjacent to the $\alpha$ globin locus. ${ }^{18}$ It is difficult to relate the finding of increased chromosomal fragility to $\alpha$ thalassaemia-mental retardation. The increased breakage in the deletional case may have predisposed to the apparent paternal germline mutation observed.

The use of pulsed field electrophoresis, with its ability to map large fragments of DNA quickly, has provided the capacity to examine adjacent regions of chromosome $16 \mathrm{p}$ for microdeletions which may not be detectable on cytogenetic analysis. None was observed with the limited pulsed field electrophoresis per- formed in our patient. Given the inability to find any abnormality of $16 p$ in the cases described so far, the unusual haematological findings, and the failure to identify any chromosomally female cases, Wilkie $e t$ $a l^{11}$ speculated whether the defect may in fact involve a gene on the $\mathrm{X}$ chromosome, coding for a transacting protein that regulates $\alpha$ globin expression. Some evidence already exists for gene(s) responsible for $\gamma$ globin regulation on the $\mathrm{X}$ chromosome. ${ }^{19} 20$ The history of another affected male sib in the present case would be consistent with this pattern of inheritance, and would be the first time that two males in a sibship have been affected. Linkage studies, using $\mathrm{X}$ chromosome probes in the available families, may shed some light on this intriguing syndrome.

We are grateful to Drs A O M Wilkie and D R Higgs for their helpful comments and for providing their unpublished data. We would also like to thank Dr A Lammi and Ms P Beale of the Department of Haematology, Royal Alexandra Hospital for Children, Camperdown, NSW, for performing red cell enzyme assays on this patient.

1 Breuning $\mathrm{MH}$, Madan K, Verjaal M, Wijnen JT, Meera Khan P, Pearson PL. Human $\alpha$-globin maps to pter-pl3.3 in chromosome 16 distal to PGP. Hum Genet 1987;76:287-9.

2 Higgs DR, Vickers MA, Wilkie AOM, Pretorius IM, Jarman AP Weatherall DJ. A review of the molecular genetics of the human alpha-globin gene cluster. Blood 1989;73:1081-104.

3 Weatherall J, Higgs DR, Bunch C, et al. Hemoglobin $\mathrm{H}$ disease and mental retardation-a new syndrome or a remarkable coincidence? $N$ Engl 7 Med 1981;305:607-12.

4 Borochowitz D, Levin SE, Krawitz S, Stevens K, Metz J. Hemoglobin-H disease in association with multiple congenital abnormalities. Clin Pediatr 1970;9:432-5.

5 Bowcock $A M$, van Tonder $S$, Jenkins $T$. The hemoglobin $H$ disease mental retardation syndrome: molecular studies on the South African case. Br $\mathcal{F}$ Haematol 1984;56:69-78.

6 Lamb J, Wilkie AOM, Harris PC, et al. Detection of breakpoints in submicroscopic chromosomal translocation, illustrating an important mechanism for genetic disease. Lancet 1989; 819-24.

7 Hutz MH, Marmitt CR, Schuler L, Salzano FM. Hereditary anemias in Brazil-new case of $\mathrm{Hb} H$ disease with mental retardation. Seventh International Congress of Human Genetics, Berlin, 1986:458A.

8 Sjolin S, Wallenius G, Wranne L. Haemoglobin Bart's and $\mathrm{H}$ in a Swedish boy. Acta Haematol (Basel) 1964;32:239-49.

9 Buckle VJ, Higgs DR, Wilkie AOM, Super M, Weatherall DJ. Localisation of human a globin to 16 pl3.3 $\rightarrow$ pter. $\mathcal{F}$ Med Genet 1988;25:847-9.

10 Wilkie AOM, Buckle VJ, Harris PC, et al. Clinical features and molecular analysis of the $\alpha$ thalassaemia/mental retardation syndromes. 1. Cases due to deletions involving chromosome band 16pl3.3. Am $\mathcal{F}$ Hum Genet (in press).

11 Wilkie AOM, Zeitlin HC, Lindenbaum RH, et al. Clinical features and molecular analysis of the $\alpha$ thalassemia/mental retardation syndromes. 2. Cases without detectable abnormality of the $\alpha$ globin complex. Am $\mathcal{F}$ Hum Genet (in press).

12 Weatherall DJ, Clegg JB. The $\alpha$ thalassaemias. In: The that assaemia syndromes. 3rd ed. Oxford: Blackwell Scientific Publications, 1981:508-644.

13 Bell GI, Karam JH, Rutter WJ. Polymorphic DNA region adjacent to the $S^{\prime}$ end of the human insulin gene. Proc Natl Acad Sci USA 1981;78:5759-63.

14 Old JM, Higgs DR. Gene analysis. In: Weatherall DJ, ed. The 
thalassaemias. Methods in haematology: Edinburgh: Churchill Livingstone, 1983:7+102.

15 Higgs DR, Goodbourn SEY, W'ainscoat JS, Clegg JB, Weatherall DJ. Highly variable regions of DNA flank the human a globin genes. Nucleic Acids Res 1981;9:4213-24.

16 Smith CL, Lawrence SK, Gillespie GA, Cantor CR, Weissman SM, Collins FS. Strategies for mapping and cloning macroregions of mammalian genomes. Methods Enzlmol 1987:151: $461-89$.

17 Smith A, Sullivan J, Evans WA. Post mortem findings in a patient with 46.XX, fra(2)(q13). I Ment Defic Res 1989;33: 87-93.
18 Sutherland GR, Hecht F. The cytogenetics of the autosomal fragile sites. In: The fragile sites on human chromosomes. New York, Oxford: Oxford University Press, 1985:16-45.

19 Miyoshi K, Kaneto Y, Kawai H, et al. X-linked dominant control of F-cells in normal adult life: characterisation of the Swiss type as hereditary persistence of fetal hemoglobin regulated dominantly by gene(s) on X chromosome. Blood 1988;72:1854-60.

20 Zon LI, Tsai SF, Burgess S, Matsudiara P, Bruns GAP, Orkin $\mathrm{SH}$. The major human erythroid DNA-binding protein $(\mathrm{GF}-1)$ : primary sequence and localization of the gene to the $\mathrm{X}$ chromosome. Proc Natl Acad Sci USA 1990;87:668-72. 